\title{
Қаржылық даму мен экономикалық өсу арасындағы байланысты талдау: өтпелі экономикалы елдер мысалында
}

\author{
А.О. Сыздықова, С. Нахипбекова, Х. Масадиков, С.Тилеуова \\ Қожа Ахмет Ясауи атындағы Халықаралық қазақ-түрік университеті
}

\section{Түйін}

Экономикалық өсудің себептерінің бірі деп саналатын қаржылық даму - соңғы жылдары әдебиетте ең көп талқыланған мәселелердің бірі. Қаржылық даму дегеніміз - елде қолданылатын қаржы құралдарының өсуі және осы құралдарды пайдалану қарқындылығы болып табылады. Жалпы алғанда, қаржылық жүйенің көлемі, мөлшері мен сапасының өзгеруі деп те анықтауға болады. Қаржылық даму мен экономикалық өсудің арасындағы себептік байланыстың бар-жоғы туралы теориялық және эмпирикалық зерттеулердің тарихы тереңде. Экономикалық өсу және экономикалық даму тұжырымдамалары әр кезеңде дамыған және дамушы елдер үшін маңызды. Өйткені бұл ұғымдар тек экономикалық қана емес, сонымен бірге әлеуметтік және саяси параметрлерді қамтитын ұзақ мерзімді процесс болып табылады.

Қаржы нарығын дамыту экономикалық өсуді арттырудағы саясат құралы бола алады деген идея қаржы нарықтарының дамуын жеделдетті. Алайда, қаржы нарығының дамуы мен экономикалық өсімнің арасындағы байланыс қайшылықтарды тудырды. Қаржылық даму мен экономикалық өсу арасындағы себептердің бағытын анықтау экономикалық өсуді арттыру саясатын анықтау тұрғысынан өте маңызды. Алайда, осы тақырыптағы эмпирикалық зерттеулер нәтиже тұрғысынан әртүрлі болғанымен, себептік бағыт бойынша консенсус жоқ.

Бұл зерттеудің мақсаты - Думитреску және Хурлин (2012) әзірлеген Грэнджердің себептілік сынағы арқылы өтпелі экономикалы елдердің қаржылық дамуы мен экономикалық өсу арасындағы байланысты зерттеу. Пайдаланылған жылдық деректер жиынтығы 1995-2018 жылдарды қамтиды. Осы зерттеудің нәтижесінде өтпелі экономикалы елдердегі қаржылық дамудан экономикалық өсуге ауысудың бір жақты себеп-салдарлық байланысы анықталды. Бұл нәтиже жеткізуші-гипотезаның осы елдерде жарамды екенін көрсетеді.

Түйін сөздер: қаржылық даму, өтпелі елдер, экономикалық өсу, панельдік себептер

\section{Анализ взаимосвязи между финансовым развитием и экономическим ростом: на примере стран с переходной экономикой}

\section{Аннотация}

Финансовое развитие, считающиеся одной из причин экономического роста, является одним из наиболее обсуждаемых вопросов в экономической литературе в последние годы. Финансовое развитие определяется увеличением используемых в стране финансовых инструментов и интенсивностью их использования.

История теоретических и эмпирических исследований существования причинно-следственной связи между финансовым развитием и экономическим ростом восходит к древним временам. Концепции экономического роста и экономического развития важны как для развитых, так и для развивающихся стран в начале каждого периода. Потому что эти понятия являются не только экономическими долгосрочными процессами, но учитывают также социальные и политические параметры. Идея о том, что развитие финансового рынка может быть политическим инструментом экономического роста, ускорила развитие финансовых рынков. Однако связь между развитием финансового рынка и экономическим ростом привела к противоречиям. Выявление причинно-следственной связи между финансовым развитием и экономическим ростом очень важно с точки зрения определения политики, направленной на ускорение последнего. Однако, хотя эмпирические исследования по этому предмету отличаются с точки зрения результатов, нет единого мнения о направлении причинно-следственной связи.

Целью данного исследования является изучение взаимосвязи между финансовым развитием и экономическим ростом в странах с переходной экономикой с помощью группового теста причинности Грейнджера, разработанного Dumitrescu and Hurlin (2012). Используемый годовой набор данных охватывает период 1995-2018 гг. В результате проведенного исследования были обнаружены односторонние причинноследственные связи от перехода от финансового развития к экономическому росту в странах с переходной экономикой. Полученный результат подтвердил верность выдвинутой гипотезы для этих стран.

Ключевые слова: финансовое развитие, страны с переходной экономикой, экономический рост, панельная причинность

\section{Analysis of the Relationship between Financial Development and Economic Growth: The Case of Transition Economies}

\section{Abstract}

Financial development, which is considered to be one of the reasons for economic growth, is one of the issues discussed in the literature in recent years. Financial development is defined as the increase in the financial instruments used in a country and the intensity of the use of these instruments. More generally, it is also possible to define the size of the financial system and the change in size and quality and quantity. The history of theoretical and empirical studies on whether there is a causal relationship between financial development and economic growth goes back to 
ancient times. The concepts of economic growth and economic development are important for both developed and developing countries at the beginning of each period. Because these concepts are not only economic, but also a longterm process involving social and political parameters.

The idea that financial market development can be a policy tool in increasing economic growth accelerated the development of financial markets. However, the relationship between financial market development and economic growth has led to controversy. To reveal the direction of causality between financial development and economic growth is very important in terms of determining policy to increase economic growth. However, although the empirical studies on this issue are different in terms of results, there is no consensus on the direction of causality.

The aim of this study is to investigate the relationship between financial development and economic growth for the transition economies through the panel Granger causality test developed by Dumitrescu and Hurlin (2012). The annual data used covers the period 1995-2018. As a result of the study, a one - way causality relationship was found in transition economies from financial development to economic growth. This result shows that the hypothesis of supply prediction in these countries is valid.

Keywords: financial development, transition countries, economic growth, panel causality

\section{Kipicпе}

Екінші дүниежүзілік соғыстан кейін пайда болған жаһандану қозғалыстарының маңызды құрамдас бөлігі әлемнің қаржылық өзара байланысы мен реттелуі болып табылады. Атап айтқанда, 1980 жылдан кейін қарқынды дамуға енген қаржы нарықтарының әсері пікірталас тудырды. Қаржылық даму мен ырықтандыруды жеткілікті жинақтамай, инвестициялық проблемаларға тап болған елдер үшін экономикалық өсудің нысаналы жоғары қарқынына қол жеткізу құралы ретінде пайдалануға бола ма деген мәселе де талқыланады.

Бұл зерттеуде өтпелі экономикалы елдердегі экономикалық өсу мен қаржылық даму арасындағы байланыс қарастырылады. Өтпелі кезеңдегі экономика - бұл өздерінің экономикалық құрылымын әлеуметтікэкономикалық құрылымнан либералды құрылымға өзгертетін елдер [1]. Бұл елдер бұрын орталықтан жоспарланған социалистік тәртіппен басқарылды, бірақ содан кейін еркін нарықтық экономика мен демократиялық қоғам орнатуға тырысты [2].

Біріккен Ұлттар Ұйымының (БҰҰ) 2014 жылғы «Әлемдік экономикалық жағдай және күтулер туралы 201» баяндамасына сәйкес өтпелі экономикалардың қазіргі тізімі төмендегідей: Албания, Босния және Герцеговина, Черногория, Сербия, Македония, Грузия, Әзірбайжан, Армения, Беларусь, Қазақстан, Қырғызстан, Молдова, Ресей, Тәжікстан, Түркіменстан, Украина және Өзбекстан. Бұл зерттеуде БҰҰ жариялаған соңғы тізімге енетін өтпелі экономикалы елдер қарастырылады.

Қаржылық дамуды қаржы институттарын, нарықтар мен қаржылық құралдардың дамуы мен өсуі деп анықтауға болады [3]. Ақша мен капитал нарығының ырықтануымен және дамуымен қаржылық даму маңызды зерттеу тақырыбынаайналды.Қаржылықжүйеніңжинақ ақшаны жұмылдыру және қарыз қаражаттарын қай қарыз алушыларға бөлу керектігін шешу арқылы қарыз алушыларға бөлінуін қамтамасыз ету функциясы салымшылардың өздерінің жинақталған қаражаттарын әртүрлі инвестициялық мүмкіндіктерге тарату және өтімділікті құру арқылы тәуекелдерін азайту әлеуетіне байланысты ұлттық экономиканы нығайтуы мүмкін [4].

Қаржылық дамуды өлшеу оңай болмайтындықтан, қаржылық даму мен өсу арасындағы байланысты зерттейтін зерттеулерде қаржылық дамуды көрсету үшін көптеген көрсеткіштер пайдаланылды. Осы зерттеулердің нәтижесінде әртүрлі тұжырымдар пайда болды $[5,6]$. Алайда, бұл зерттеулердің жалпы консенсусы қаржылық даму мен экономикалық өсімнің арасында оң байланыс бар екендігі болып табылады.

Бұл зерттеуде өтпелі экономикалы елдердегі қаржылық даму мен экономикалық өсудің арасындағы байланысты зерттеу мақсатында алдымен, әдебиеткешолу жасалады, содан кейін мәліметтер жиынтығы мен эконометриялық әдіс түсіндіріледі. Зерттеудің эмпирикалық нәтижелерін талқылағаннан кейін зерттеу қорытындымен аяқталады.

Әдебиеттерге шолу.

Экономикалық өсудің нысаналы бағыттарына қатысты саясаттың мазмұны теориялық, сонымен қатар саяси деңгейде де күрделі және қарама-қайшы болуы мүмкін. Қаржы нарықтары мен экономикалық өсу арасындағы қатынастар теориялық және эмпирикалық нәтижелер тұрғысынан айтарлықтай ерекшеленеді. Мысалы, неоклассикалық өсу теориясында қаржылық дамуға ешқандай рөл бөлінбейді. Осы модельдерге сәйкес, қаржы нарығының экономикалық өсуге әсері уақытша, сондықтан қаржы нарықтарының кеңеюі экономикалық өсуге деңгейлік әсер етеді. Яғни, бұл жан басына шаққандағы кірісті ұлғайта алады, бірақ ол үнемі өсу қарқынын арттыра алмайды. МакКиннон мен Шо гипотезасына сәйкес, либералды қаржы нарығын институциоландыру жинақ мөлшерлемелерінің өсуіне және 
пайыздық мөлшерлемелердің төмендеуіне әкеледі, осылайша инвестицияларды ұлғайту арқылы экономикалық өсуді тездетуі мүмкін. Бұл қаржылық дамудың ішкі өсу моделінің шеңберіндегі өсуге әсер етуі мүмкін екенін көрсетеді.

Қаржылық даму мен экономикалық өсімнің арасындағы байланысты теориялық зерттеуді алғаш рет 1912 жылы Шумпетер жасаған. Осы теорияға негізделген зерттеулер негізінен екі гипотезаға сәйкес (ұсыныс пен сұранысқа негізделген) қаржылық даму мен өсу арасындағы байланысты түсіндіруге тырысты [7]. «Ұсынысқа негізделген» гипотезаға сәйкес, қаржы жүйесі капиталдың өсуін және технологиялық дамуға қажетті қаражатты қамтамасыз ете отырып, өсу процесін жеделдетеді. «Сұранысқа негізделген» гипотезада нақты сектордың өсуі есебінен қаржыландыруға сұраныс қаржы секторын дамытудың жаңа перспективасын ашады. Осы тәсілден көрініп тұрғандай, нақты сектордың өсуіне байланысты қаржылық қызметтерге деген қажеттілік қаржылық дамуды қоздырады.

Қаржылық дамудың экономикалық өсудегі рөліне байланысты көптеген эмпирикалық зерттеулер жасалған. Эмпирикалық модельдер жақсы дамыған қаржы нарықтары ресурстарды бөлудің тиімділігін арттырып, ұзақ мерзімді перспективада бірнеше арналар бойынша өсуді тездететінін көрсетті. Голдсмит (1969) 35 елдегі қаржылық дамудың экономикалық өсумен байланысын алғашқы болып зерттеген ғалымдардың бірі болып есептеледі және ол айнымалылар арасында оң қатынасты тапқан. Келесі зерттеулердің көпшілігінде екі негізгі индикатордың бірі пайдаланылды, атап айтқанда банктердің жеке секторға берген несиелерінің немесе қор биржаларының мөлшері экономикалық өсу кезіндегі қаржылық дамудың рөлін өлшеу үшін қолданылды [8].

Өзінің зерттеуінде Гирмай (2004) Африкалық Сахараның 13 елінде қаржылық даму мен экономикалық өсімнің арасындағы байланысты анықтау үшін VAR моделін қолданды. Бұл зерттеуде экономикалық өсу нақты ЖІӨ өсуімен өлшенеді, ал қаржылық даму жеке делдалдарға қаржы делдалдары берген несие деңгейімен өлшенеді. Коинтеграциялық талдау нәтижесінде кем дегенде 12 елде қаржылық даму мен экономикалық өсімнің арасында ұзақ мерзімді байланыс бар екендігі анықталды. Қарым-қатынастың даму бағыты 8 мемлекетте қаржылық дамудан экономикалық өсуге, ал 5 елде екі бағытта байланыс бар екендігі байқалады [9].

Батыс Африканың 12 елінің деректерін қолдана отырып Атиндеху, Гуей және
Аменоунве (2005) зерттеулер жүргізген. Мұнда үш көрсеткіш қаржылық дамуды бейнелеу үшін қолданылады. Экономикадағы ішкі қарыздар, өтімді қарыздар (қаржы жүйесінің өтімді қарыздарының ЖІӨ-ге қатынасы) және өтімді резервтер (банктің өтімді резервтерінің банк активтеріне қатынасы. Жан басына шаққандағы нақты ЖІӨ экономикалық өсудің көрсеткіші ретінде қарастырылады. Бұл зерттеуде ЭнглГрэнджердің себептілік сынағымен қаржылық айнымалы мен өсетін айнымалылар арасындағы байланыс талданды. Елдер арасында тек Мавритания мен Сьерра ғана экономикалық өсу мен несие арасындағы себепті анықтады. Сонымен бірге өсім Буркина-Фасо мен Мавританияны қоспағанда, несиелік қарыз алуға себеп болмағаны анықталды. Керісінше, Кот-д’Ивуар, Гамбия, Сьерра-Леоне және Мали несиелік қарыз алудың экономикалық өсуге ықпал еткені анықталды. Кот-д’Ивуар мен Мавритания сұйық қорлар экономикалық өсуге себеп болады десе, ал Гана мен Сенагал себепсалдарлық байланысы жоқ деген тұжырым жасады [10].

Мехл және басқалар (2006) 1993-2003 жж. аралығында қаржылық тереңдеудің ОңтүстікШығыс Еуропа елдеріндегі экономикалық өсуге әсер етпейтінін анықтаған. Бұл ретте қаржы делдалдығы мен ақшамен алмастыру операциялары өсу қарқынына теріс әсер етеді, ал шетел банктерінің ену деңгейі және кредиторлардың жоғары қорғалуы экономикалық өсуге оң әсер етеді [11].

Анг және Маккиббин (2007) зерттеуі 1960-2001 жж. деректерімен Малайзияның экономикалық өсуіне қаржылық дамудың әсерін зерттеді. Бұл елде бизнес капитал нарығынан гөрі банктердің қаржыландыру қажеттіліктерін қанағаттандырғанды жөн көреді. Зерттеудің нәтижелері қарастырылған кезде, Малайзиядағы қаржылық ырықтандыру қаржылық қысым саясатын бейтараптандыру арқылы қаржы секторының дамуына ықпал етеді. Бұл ретте қаржылық даму мен өсу арасында оң байланыс бар [12].

Хан және Каюм (2007) зерттеуінде 19612005 жж. мәліметтерін қолдана отырып, Песаран және басқалармен (2001) жасаған ARDL тәсілінің негізінде Пәкістан экономикасының өсуіне қаржылық дамудың әсерін зерттеді. Алынған нәтижелер нақты ішкі жалпы өнім мен қаржылық даму арасында ұзақ мерзімді каузальды байланыс бар екенін көрсетеді [13].

Кеноргис және Самитас (2007) Польшаны зерттеу кезінде жеке меншік сектордағы несиелер ұзақ мерзімді экономикалық өсудің негізгі қозғаушы күші болды деп мәлімдеді. Сонымен қатар, экономикалық өсу мен 
қаржылық даму арасында оң байланыс бар деген қорытындыға келген [14].

Хагмайр және басқалар (2007) ОңтүстікШығыс Еуропа елдері үшін қаржылық даму мен экономикалық өсу арасындағы байланысты талқылады. Аймақтағы дамып келе жатқан төрт түрлі экономиканы қамтыған олардың талдауында олар облигациялар нарығы мен акционерлік капитал экономикалық өсуге оң және маңызды әсер етті [15].

Saci және Holden (2008) қаржылық дамудың 1988-2001 жылдардағы деректерді қолдану негізінде панельдік мәліметтер негізінде 30 дамушы елдердегі экономикалық өсуге әсерін зерттеді. Авторлар қор нарығындағы және қаржылық делдалдық қызметіндегі дамуды көрсететін 10 түрлі айнымалыны қаржылық даму көрсеткіші ретінде қолданды. Эмпирикалық нәтижелер көрсеткендей, дамыған қаржы жүйесі бар елдер тез өседі [16].

Агаев пен Ямак (2009) зерттеуінде Тәуелсіз Мемлекеттер Достастығына мүше 12 мемлекеттің экономикалық өсуіне әсер ететін детерминанттарды панельдік әдіспен анықтауға тырысты. Зерттеу нәтижелеріне сәйкес, демократияландырудың өсуге әсері айқын болмаса да, құрылымдық реформалар мен макроэкономикалық тұрақтылықтың өсуі экономикалық өсуге әсер етеді. Бұл елдердің халықаралық қауымдастыққа бірігуі экономикалықөсугеоңәсеретті[17].Агаев(2012) зерттеуінде ырықтандыру реформаларының, бюджет тапшылығы мен сыртқы сауданың дамуы 25 өтпелі экономикадағы экономиканың өсуіне әсерін қарастырды. Зерттеулерге сәйкес, өтпелі экономикалы елдердегі құрылымдық қайта құру және нарықтық экономика үшін бюджет тапшылығын азайту экономикалық өсуге әсер етеді [18].

Altintas және Ayrıçay (2010) Түркиядағы қаржылық даму және экономикалық өсу арасындағы қатынастарды 1987 -2007 жылғы кезеңде үш айлық деректерді қолдана отырып ARDL шектері сынақ көзқарасқа негізделген әдіс арқылы зерттеді. Модельді бағалауға сәйкес, нақты өсу, қаржылық даму, ашықтық және нақты пайыздық мөлшерлеме арасында ұзақ мерзімді коинтеграциялық байланыс бар. Болашақта қаржылық даму коэффициентінің $1 \%$ өсуі экономикалық өсуді 0,30\% арттырды [19].

Аднан Хи және Ислам (2013) Бангладештегі қаржылық даму мен экономикалық өсім арасындағы байланысты зерттеу үшін негізгі компоненттерді талдау арқылы қаржылық даму индексін жасады. Бұл елдің қаржы секторы банктерге негізделген даму тенденциясын ұстанып отырғандықтан, қаржылық даму индексі үкіметтің реттеуді және институционалды құрылымын өлшеуге арналған. Басқаша айтқанда, қаржылық даму индексі банк секторына бағытталған (өйткені ол қаржы нарығының 95 пайызын құрайды). Эмпирикалық нәтижелер қаржылық дамудың экономикалық өсуге әсері теріс екенін көрсетеді [20].

Джедидиа және басқалар (2014), қаржылық даму Тунистегі экономикалық өсуді қолдай ма, жоқ па деген тәжірибелік зерттеу жүргізді. Зерттеуде авторлар қаржылық дамуды көрсету үшін жеке несиелер мен жеке нарықтар, қор нарығын дамыту және эмитент банктің бағалы қағаздары сияқты көрсеткіштерді пайдаланды. ARDL зерттеулерінің нәтижелері бойынша жеке секторға берілген ішкі несиелер экономикалық өсуге оң әсер етті және қаржылық даму ұзақ мерзімді перспективада экономикалық өсудің қозғаушы күші болды. Алайда қысқа мерзімді қаржылық дамудың қаржылық әлсіздікке әкелетіні анықталды. Сонымен қатар жеке несие мен экономикалық өсімнің екі жақты себеп-салдарлық байланысы расталды. Басқа нәтижелер қор нарығының дамуы да, банктердің қор нарығына араласуы да экономикалық өсуге күшті және оң әсерін тигізбейді. Сондықтан авторлар Туниске ең алдымен, қор нарығындағы жинақтарды жеделдету және ұзақ мерзімді экономикалық өсуді қолдау үшін қаржылық реформаларын жеделдету керек деп санайды [21].

Батуо және басқалар (2018), Африканын 41 еліндегі 1985-2010 жылдар аралығындағы қаржылық тұрақтылық, қаржылық ырықтандыру, қаржылық даму және экономикалық өсу арасындағы байланысты бағалайды. Нәтижелерге сәйкес қаржылық даму және қаржылық ырықтандыру қаржылық тұрақтылыққа оң әсер етеді. Сонымен қатар Африка елдеріндегі экономикалық өсімнің қаржылық тұрақсыздықты төмендететіні және қаржылық тұрақсыздық ырықтандырудан кейінгі кезеңге қарағанда одан бұрыңғы кезеңде жоғары екендігі байқалды [22].

Соултанаева (2010) Балтық жағалауы елдерінің үшеуі - Латвия, Эстония және Литва үшін қаржылық даму мен экономикалық өсу арасындағы байланыс туралы тоқсан сайынғы деректерді талдайды. 1995-2008 жылдар аралығын қарастырған өз зерттеуінде автор VAR (векторлық авторегрессивті модель) әдісін таңдаған, кейінірек Ли мен Маддала (1997) Boostrap критикалық мәндерді қолданған. Қолданудан алынған нәтижелерде банк секторының дамуы ұзақ мерзімді перспективада экономикалық өсуге әкелуі мүмкін деген [23]. 
Кожокару және басқалары (2011) бұрынғы коммунистік Орталық және Шығыс Еуропа елдері мен Тәуелсіз Мемлекеттер Достастығы елдерінде қаржылық дамудың экономикалық өсуге әсерін түсіну үшін GMM әдісін (Generalized method of moments) сынап көрді. 1990-2008 жж. жүргізген зерттеулерінде қаржылық тереңдік пен тиімділігін көрсететін көптеген суррогаттық айнымалылар қолданылды. Зерттеуден алынған нәтижелер: жеке сектордың несиелері экономикалық өсуге оң әсер етеді, бірақ инфляция деңгейі жоғары болған жағдайда бұл оң әсер статистикалық тұрғыдан маңызды емес. Жоғары пайыздық мөлшерлемелер банкаралық бәсекелестікті төмендетеді және экономикалық өсуге кедергі келтіреді [24].

Айдын және басқалар (2014) Түркия экономикасы үшін 1991-2009 жж. кезеңіндегі қаржылық даму мен экономикалық өсім арасындағы байланысты тексерді. Авторлар ұзақ мерзімді перспективада айнымалылар арасында оң байланыс таба алмады. Олар бұл нәтижеге қол жеткізудің себебі қаржылық еркіндіктер аясының кеңеюіне және ақша массасының кеңеюінде экономикалық өсуге теріс әсері деп мәлімдеді [25].

Мержан мен Гөчер (2013) 1980-2010 жж. БРИК-Т елдерін талдаған зерттеулерінде қаржылық даму мен экономикалық өсу арасында бір жақты және оң байланыс бар екенін анықтады [26].

Дудиан және Попа (2013) Орталық Азия мен Шығыс Еуропаның сегіз мемлекеті үшін қаржылық даму мен экономикалық өсу арасындағы байланысты талдады. Қаржылық дамуды өлшеу үшін олар алатын айнымалылар: ақша анықтамасының жылдық өсу қарқыны, ЖІӨ-ге жеке секторға берілген ішкі қарыздардың үлесі, пайыздық мөлшерлеме және несиелердің жалпы көлеміндегі жұмыс істемейтін қарыздардың үлесі. Тәуелді өзгергіштік - бұл ЖІӨ-нің жылдық өсу қарқыны. Төрт түрлі сценарийлерді жасау арқылы айнымалылар арасындағы байланысты сынайтын зерттеулерден алынған нәтижелер; нашар несиелер және пайыздық мөлшерлемелердің таралуы экономикалық өсуге айтарлықтай теріс әсер етеді. Жеке ішкі қарыздар үлесінің артуына қарамастан, жеке сектордағы несиелер мен ақша массасының өсуі (М2) ЖІӨ-ге оң әсер етеді [27].

Акынжы және т.б. (2014), 1980-2011 жж. деректерімен ЭЫДҰ мүше-мемлекеттері үшін Педрони мен Као коинтеграциялық тестке талдау жасады. Олар қаржылық даму мен экономикалық өсу арасында ұзақ мерзімді бірлескен байланыс бар екенін анықтады.
Грэнджер панелінің себептік талдауына сәйкес айнымалылар арасындағы себеп-салдарлық байланыс сұранысқа негізделген [28].

Арыч (2014) Еуропалық Одақтың 27 елі үшін 2004-2012 жылдардағы қаржылық даму мен экономикалық өсу арасындағы байланысты зерттеді. Оның талдауының нәтижелері бойынша, халықаралық қаржы дағдарысының салдары терең сезінген 2009 жылды қоспағанда, қаржылық даму мен экономикалық өсімнің арасында оң байланыс бар. Айнымалылар арасындағы себептік байланыс қаржылық дамудан экономикалық өсуге дейінгі бір жолды құрайды [29].

Петковски мен Кжосевски (2014) Орталық және Оңтүстік-Шығыс Еуропа өтпелі экономикалы 16 елді GMM әдісі бойынша сынақтан өткізді. Қаржылық дамуды білдіретін айнымалылар; жеке сектордың несиелері, пайыздық мөлшерлемелер және ақшаға ұқсас активтер. 1991-2011 жж. деректерінен алынған өтінімдерге сәйкес жеке сектордың несиелері мен пайыздық мөлшерлемелер арасындағы маржа экономикалық өсуге теріс әсер етті, ал ақшалай активтердің экономикалық өсуге әсері оң болды [30].

Обрадович пен Грбич (2015) Сербияның қаржылық дамуы мен экономикалық өсуі арасындағы байланысқа 2004-2011 жж. тоқсандық деректерді пайдалана отырып талдау жасады. Тодо Ямамото себептеріне талдау жасау бойынша, экономикалық өсу қаржылық тереңдеуге ықпал етеді. Сондай-ақ олар жеке кәсіпкерлер мен үй шаруашылығы несиелерінің ЖІӨ-дегі үлесі мен экономикалық өсу арасында бір жақты себеп-салдарлық байланыс бар екендігіне назар аударады. Қаржылық емес жеке сектордың жалпы ішкі қарыздардағы үлесі мен экономикалық өсімнің арасындағы екі жақты себеп-салдарлық байланыс бар. Жоғарыда келтірілген зерттеулерден көрініп отырғандай, қаржылық даму мен экономикалық өсімнің арасында ұзақ мерзімді себепті байланыс бар. Бұл қатынастардың бағыты бір немесе екі бағытты болуы мүмкін. Немесе айнымалылар арасында; Зерттеуге жататын елдер мен елдер тобы арасында ешқандай байланыс жоқ екендігі байқалады [31].

\section{Әдіснама}

Деректер.Қаржылық даму мен экономикалық өсудің арақатынасын зерттейтін бұл зерттеуде жан басына шаққандағы ЖІӨ-нің өсу қарқыны экономикалық өсудің көрсеткіші ретінде, ал банктік сектор ұсынатын ішкі қарыздардың ЖІӨ-ге қатынасы қаржылық дамудың көрсеткіші ретінде пайдаланылды. Сондай-ақ, модельге экономикалық өсуге әсер 
ететін басқа айнымалылар (ақша массасы, инфляция және сауда көлемі) енгізілген (1-кесте).

Жоғарыда аталған 17 өтпелі елдің 15-і талдауға қосылды. Деректер жеткіліксіз болғандықтан, Түркіменстан мен Өзбекстан талдаудан шығарылды. Өтпелі экономикалы елдердің 1995-2018 жж. арасындағы мәліметтер
Дүниежүзілік банктен алынды. Жалпы өтпелі кезең 1989 жылы басталып, 1995 жылға дейін белгісіз түрде жалғасты. Сондықтан осы зерттеуде 1995 жылдан кейінгі кезеңді қамтитын өтпелі кезең зерттелген. Бұл зерттеуде эконометрикалық талдау үшін Stata14 пакеттік бағдарламасы қолданылды.

Кесте 1 - Айнымалылардың анықтамалары

\begin{tabular}{|c|c|c|}
\hline Айнымалылар & Анықтама & Дереккөз \\
\hline growth & ЖІӨ өсу қарқыны & \multirow{5}{*}{ Дүниежүзілік банк } \\
\hline money & $\begin{array}{l}\text { Ақшаның кеңейтілген анықтамасының ЖІӨ- } \\
\text { ге қатынасы }\end{array}$ & \\
\hline credit & $\begin{array}{l}\text { Банктердің жеке секторға берген несиелерінің } \\
\text { ЖІӨ-ге қатынасы }\end{array}$ & \\
\hline $\inf$ & Инфляция (тұтыну бағасы) & \\
\hline trade & $\begin{array}{l}\text { Импорт пен экспорт көлемінің ЖІӨ-ге } \\
\text { қатынасы }\end{array}$ & \\
\hline
\end{tabular}

Думитреску мен Хурлин (2012) мәлімдегендей, кез-келген экономикалық құбылыс тұрғысынан елге қолданылатын себептік қатынастар басқа елдер үшін де жарамды болуы әбден мүмкін. Сондықтан, себептік байланыстарды панельдік деректер аймағында көбірек бақылаулармен тиімді тексеруге болады.

Думитреску мен Хурлин (2012) гетерогенді панельдер үшін Грэнджер себептілік сынағының кеңейтілген нұсқасын ұсынды. Бұл сынақ Грэнджердің себебін анықтау сынағының көлденең қимасы үшін есептелген жеке Валд сынақтарының орташа мәнін білдіреді. Думитреску мен Хурлин (2012) сынақтарының тағы бір артықшылығы - бұл коинтеграциялық қатынастарды елемейді.

Бұл әдістің басқа артықшылықтары; панельді құрайтын елдер арасындағы көлденең қиманың тәуелділігі мен гетерогенділікті қарастыру, уақыт өлшемі (Т) көлденең қимадан (N) үлкен болған кезде екеуін де қолдану және тұрақсыз мәліметтер жиынтығында тиімді нәтиже беру [32]. Думитреску мен Хурлин сынақтарының тағы бір ерекшелігі ол біріктірілген қарым-қатынастың болуы мен болмауында да талдай алады.

Dumitrescu-Hurlin панелінің себепсалдарлық сынағында, және екі уақыт ішінде байқалған екі стационарлық процесті саны үшін, уақыттың әр бірлігі () үшін, (1). теңдеудегі сызықтық гетерогенді модельді қолданады:

$$
Y_{i t}=\sum_{k=1}^{K} \gamma_{i}^{(k)} Y_{i t-k}+\sum_{k=1}^{K} \beta_{i}^{(k)} X_{i t-k}+\varepsilon_{i t}
$$

Мұндағы: $K$ - оңтайлы кідіріс ұзақтығы. Тесттің нөлдік гипотезасы - бүкіл көлденең қималарда “ $X$ 'тен $Y$ ' ге себеп салдарлық қарым қатынас жоқ.

\section{Амирикалық нәтижелер жсәне бавалау}

Кросс-секциялық тәуелділік тесті. Зерттеудің бірінші кезеңінде Грэнджердің себебін талдауда қолданылатын панель мәліметтерінде кросс-секциялық тәуелділік деңгейі мен стационарлық қасиеттері зерттеледі. Айнымалылар арасындағы көлденең тәуелділіктің болуы нәтижелерге айтарлықтай әсер етеді. Сондықтан талдауды бастамас бұрын, көлденең тәуелділікті тексеріп, бірлік түбірін және басқа да тексеру әдістерін таңдау кезінде ескеру қажет. Әйтпесе, талдау дұрыс емес нәтиже беруі мүмкін [33].

Егер уақыт өлшемі панельдік деректер модельдеріндегі көлденең өлшемнен үлкен болса, Брейш пен Паган (1980) және Песаран, Уллах, Ямагата (2008) сынақтарына артықшылық берілуі керек. Әйтпесе, Фридман (1937), Фрейм (1995) және Песаран (2004) көлденең тәуелділік сынақтарын қолдануға болады [34]. Бұл зерттеуде уақыт және көлденең қималар бір-біріне жақын болғандықтан, Брейш пен Паган (1980), Песаран (2004) және Песаран, Уллах, Ямагата (2008) сынақтары қолданылып, нәтижелері 2-кестеде көрсетілген. 
Кесте 2 - Кросс-секциялық тәуелділік тестінің нәтижелері

\begin{tabular}{|l|c|c|c|}
\hline \multicolumn{1}{|c|}{ Айнымалылар } & CD $_{\text {LM1 }}-$ тесті & CD $_{\text {Lu2 }}-$ тесті & LM $_{\text {adj }}$ тесті \\
\hline growth & 367.347 & 9.093 & 5.737 \\
& $(0.000)$ & $(0.000)$ & $(0.000)$ \\
\hline monry & 371.433 & 8.370 & 2.177 \\
& $(0.000)$ & $(0.000)$ & $(0.014)$ \\
\hline credit & 1017.607 & 39.407 & 5.372 \\
& $(0.000)$ & $(0.000)$ & $(0.000)$ \\
\hline inf & 312.303 & 4.992 & 3.249 \\
& $(0.000)$ & $(0.000)$ & $(0.001)$ \\
\hline trade & 374.076 & 8.044 & 4.244 \\
& $(0.000)$ & $(0.000)$ & $(0.000)$ \\
\hline growth=f(money,credit,inf,trade) & 600.644 & 19.061 & 31.972 \\
& $(0.000)$ & $(0.000)$ & $(0.000)$ \\
\hline
\end{tabular}

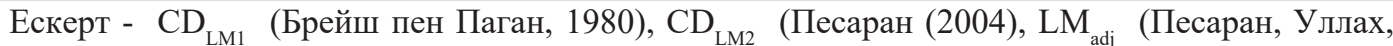
Ямагата, 2008) сынақтарын көрсетеді. Тесттік статистикалық мәндердің ықтималдық мәні жақшада көрсетілген.

Кросс-секциялық тәуелділік тестінің $\left(\mathrm{CD}_{\mathrm{LM} 1}, \mathrm{CD}_{\mathrm{LM} 2}\right.$ және $\left.\mathrm{LM}_{\mathrm{adj}}\right)$ нәтижелеріне сәйкес гипотезасы қабылданбайды. Осы нәтиже панель бірлік түбір сынақтарында ескерілуі қажет.

Панель бірлік түбір тесті. Бірлік түбір дегеніміз уақыт бойынша дисперсия мен орташа мәннің тұрақты екенін және екі кідіртілген уақыт кезеңіндегі айнымалылардың ковариациясы уақыт бойынша емес, ауыспалылардың арасындағы кідіріске байланысты болатындығын білдіреді [35].

Панель бірлік түбір тесттері өз кезегінде бірінші және екінші буын тесттері болып екіге бөлінеді. Бұның басты себебі бірінші буын тесттер панель мәліметтері құраған кросс секциялық деректер арасында тәуелділік жоқ гипотезасы негізінде құрылған болса, екінші буын бірлік түбір тесттер кросс секциялық тәуелділікті ескереді.

Талдаудың бірінші сатысында зерттеуде екінші буынның түбірлік сынағы қолданылды, өйткені көлденең тәуелділікті тексеру нәтижесінде сериялар арасындағы бірліктер арасында байланыс болды. 3-кестеде сериялардың кросс секциялық тәуелділігін ескеретін Pesaran CADF түбірлік сынақ нәтижелері көрсетілген.

Кесте 3- Pesaran CADF панель бірлік түбір тестінің нәтижелері

\begin{tabular}{|c|c|c|c|c|c|}
\hline \multirow[b]{2}{*}{ Айнымалылар } & \multicolumn{2}{|r|}{ Дәреже } & \multicolumn{2}{|c|}{ Бірінші дәрежеден айырым } & \multirow[b]{2}{*}{ Қорытынды } \\
\hline & $\begin{array}{c}\text { Тұрақты } \\
\text { парметрлі }\end{array}$ & \begin{tabular}{|c|} 
Тұрақты парметрлі \\
және трендті
\end{tabular} & $\begin{array}{c}\text { Тұрақты } \\
\text { парметрлі }\end{array}$ & \begin{tabular}{|c|} 
Тұрақты парметрлі \\
және трендті \\
\end{tabular} & \\
\hline büуӥте & -3.131 & -2.998 & - & - & $\mathrm{I}(0)$ \\
\hline para & -2.218 & -2.091 & -2.844 & -3.358 & $\mathrm{I}(1)$ \\
\hline kredit & -1.725 & -1.823 & -2.550 & -3.323 & $\mathrm{I}(1)$ \\
\hline tüfe & -3.908 & -4.301 & - & - & $\mathrm{I}(0)$ \\
\hline ticaret & -1.964 & -2.168 & -2.770 & -2.966 & $\mathrm{I}(1)$ \\
\hline$\% 10$ & -2.110 & -2.630 & -2.100 & -2.630 & \\
\hline$\% 5$ & -2.200 & -2.720 & -2.210 & -2.730 & \\
\hline$\% 1$ & -2.380 & -2.880 & -2.400 & -2.920 & \\
\hline
\end{tabular}

Тестілеу нәтижелері бойынша, үлкен ақша массасының ЖІӨ-ге қатынасы (money), банк секторының жеке секторға берген қарыздарының ЖІӨ-ге қатынасы (credit) және экспорт-импорттың жалпы көлемінің
ЖІӨ-ге қатынасы (trade) айнымалыларында бірлік түбір бар екені және бірінші дәрежеден айырымы алынғанда бұл айнымалылардың мәндері стационарлы болатындығы анықталды. Сонымен қатар, өсу қарқыны (growth) және 
инфляция деңгейінің (inf) өзгермелі мәндері дәрежеде стационарлы екендігі 3-кестеде көрсетілген.

Барлық сериялардың бірдей стационарлы болмағандықтан коинтеграциялық талдауды жүргізу мүмкін емес, сондықтан айнымалылар арасындағы себептік байланыстар қарастырылды.

Думитреску және Хурлин (2012) mесті. Гетерогенді және кросс секциялық тәуелділігі бар панельдік деректер моделі үшін Думитреску және Хурлин (2012) жасаған себептілік сынағының нәтижелері 4-кестеде келтірілген. Себептерді талдауда айнымалылар стационарлы күйінде пайдаланылды.

4-кестеде Z-bar және Z-bar tilde сынақ статистикасы көрсетілген. Думитреску мен Хурлин (2012) $T>N$ болған кезде асимптотикалық таралуы бар Z-bar статистикалық тест пайдаланылады, ал $\mathrm{T}<\mathrm{N}$ $T<N$ жағдайында жартылай асимптотикалық таралуы баp Z-bar tilde статистикалық тест ұсынылады [36].

Кесте 4 - Думитреску және Хурлин (2012) тест нәтижелері

\begin{tabular}{|c|l|l|l|}
\hline$H_{0}$ гипотезі & \multicolumn{1}{|c|}{ Тест } & \multicolumn{1}{|c|}{ Статистика } & \multicolumn{1}{|c|}{ Ықтималдылық } \\
\hline growth $\nRightarrow$ money & Z- bar & 2.3313 & 0.0198 \\
& Z- bar tilde & 1.5449 & 0.1337 \\
\hline money $\nRightarrow$ growth & Z- bar & 0.1292 & 0.3457 \\
& Z- bar tilde & -0.2067 & 0.7651 \\
\hline growth $\nRightarrow$ credit & Z- bar & 0.4876 & 0.3079 \\
& Z- bar tilde & 0.0783 & 0.2013 \\
\hline credit $\nRightarrow$ growth & Z- bar & 4.1371 & 0.0000 \\
& Z- bar tilde & 2.9813 & 0.0025 \\
\hline growth $\nRightarrow$ inf & Z- bar & 1.6058 & 0.1097 \\
& Z- bar tilde & 1.0011 & 0.2709 \\
\hline inf $\nRightarrow$ growth & Z- bar & 4.7978 & 0.0000 \\
& Z- bar tilde & 3.5763 & 0.0001 \\
\hline growth $\nRightarrow$ trade & Z- bar & 0.7759 & 0.4092 \\
& Z- bar tilde & 0.3072 & 0.7076 \\
\hline trade $\nRightarrow$ growth & Z- bar & 3.0101 & 0.0026 \\
& Z- bar tilde & 2.0845 & 0.0373 \\
\hline credit $\nRightarrow$ trade & Z- bar & -0.3981 & 0.8076 \\
& Z- bar tilde & -0.7663 & 0.5531 \\
\hline trade $\nRightarrow$ credit & Z- bar & 4.3808 & 0.0000 \\
& Z- bar tilde & 2.7805 & 0.0032 \\
\hline
\end{tabular}

Ескерту: бос гипотеза; «Тәуелсіз айнымалы тәуелді айнымалының Грэнджер себебі емес».

Барлық түсіндірме айнымалылар мен экономикалық өсу арасындағы себеп-салдарды талдау нәтижелері бойынша қаржылық дамудан экономика өсу айнымалысына бір жақты себепсалдарлық байланыс бар екендігі анықталды. Алайда, экономикалық өсуден қаржылық даму айнымалысына бағытталған себепсалдарлық байланыс жоқ. Екінші жағынан, өтпелі экономикалы елдерде ашықтық пен инфляция айнымалыларынан экономикалық өсу айнымалысына бір жақты себеп-салдарлық байланыс бар. Тағы бір нәтиже импорт пен экспорттың көлемінен банк секторының жеке секторға берген заемдарға дейінгі бір жақты себеп-салдарлық байланысы бар екендігін көрсетеді.

\section{Корытынды}

Бұл мақалада өтпелі экономикалы елдердегі қаржылық даму мен өсу арасындағы байланыс 1995-2018 жж. деректерін қолдана отырып, панельдік деректерді талдау әдісімен зерттелген. Зерттеуде қолданылатын панельдік мәліметтер жиынтығы үшін, ең алдымен, көлденең тәуелділік зерттеліп, бірлік түбірлік сынақ жүргізілді. Содан кейін айнымалылар арасындағы байланысты анықтау үшін Думитреску мен Хурлиннің себептілік сынағы (2012) қолданылды. Бұл зерттеуде банктік сектордың жеке секторға берген қарыздарының ЖІӨ-ге қатынасы қаржылық дамуды көрсету үшін қолданылды және өтпелі экономикалы елдердегі ЖІӨ-нің өсу қарқыны экономикалық өсудің көрсеткіші ретінде қолданылды. 
Сонымен бірге модельге экономикалық өсуге әсер ететін басқа айнымалылар (ақша массасы, инфляция деңгейі және сауда көлемі) енгізілді. Барлық түсіндірме айнымалылар мен экономикалық өсу арасындағы себепсалдарды талдау нәтижелері бойынша өтпелі экономикалы елдердегі қаржылық даму осы елдердегі экономикалық өсуге оң әсерін тигізеді.

Бұл болжам бойынша, елдегі қаржы нарықтары мен институттардың дамуы нақты сектордың дамуына ықпал етеді және экономикалық өсуді қамтамасыз етеді. Қаржы нарықтарының дамуы экономикалық өсуге жеделдететін әсер етеді, бұл жеке тұлғаларды және корпорацияларды қорларын үнемдеуге ынталандырады, жинақ ақшаны тиімді бөлуді қамтамасыз етеді және оларды тиімді пайдалану аймақтарына бөледі.

Сондықтан өтпелі экономикалы елдерде экономикалық өсуді жүзеге асыру үшін құрылымдық қайта құру және қаржылық және коммерциялық ырықтандырудың макроэкономикалық саясатына қолдау көрсету керек деп айтуға болады. Бұл тұрғыда макроэкономикалық тұрақтылықты сақтайтын және ұстап тұратын, экономиканың сыртқы экономикалық қатынастарға ашықтығын арттыратын, ресурстарды неғұрлым өнімді инвестицияларда ресурстарды пайдалану арқылы физикалық және адами капиталды арттыратын саясат қаржылық дамуға және осылайша экономикалық өсуге оң әсер етеді. Осы елдердің қаржы нарығын нығайтатын ісшараларды мемлекеттік қолдау экономикалық өсуді қамтамасыз етуде маңызды болып табылады. Тұрақты экономикалық өсуге қол жеткізуде экономикалық өсу мен қаржылық даму арасындағы оң өзара әрекеттестік қаржылық реформалар мен ырықтандыру арқылы қолдау табуы керек.

\section{Пайдаланылван ддебиеттер}

1 Syzdykova A. Doğrudan yabancı yatırımlar ve ekonomik büyüme ilişkisi: geçiş ülkeleri için panel veri analizi //Journal of Research in Economics. - 2020. - T. 4. - N 1. - C. 78-90.

2 Williamson O. E. Transaction cost economics //Handbook of new institutional economics. - Springer, Berlin, Heidelberg, 2008. - C. 41-65.

3 Hassan M. K., Sanchez B., Yu J. S. Financial development and economic growth: New evidence from panel data //The Quarterly Review of economics and finance. - 2011. - T. 51. - N 1. - C. 88-104.

4 Liang Q., Jian-Zhou T. Financial development and economic growth: Evidence from China //China economic review. -2006 . - T. 17. - N 4. - C. 395-411.
5 Ductor L., Grechyna D. Financial development, real sector, and economic growth //International Review of Economics \& Finance. - 2015. - T. 37. - C. 393-405.

6 Ayadi R. et al. Financial development, bank efficiency, and economic growth across the Mediterranean //Economic and social development of the Southern and Eastern Mediterranean countries. Springer, Cham, 2015. - C. 219-233.

7 Ak M. Z., Altıntaş N., Şimşek A.S. Türkiye'de finansal gelişme ve ekonomik büyüme ilişkisinin nedensellik analizi// Doğuş Üniversitesi Dergisi. - 2016. - T. 17. - N 2. - C. 151-160.

8 Afşar A. Finansal gelişme ile ekonomik büyüme arasındaki ilişki //Muhasebe ve Finansman Dergisi. - 2007. - N 36. - C. 188-198.

9 Ghirmay T. Financial development and economic growth in Sub-Saharan African countries: evidence from time series analysis //African Development Review. - 2004. - T. 16. - N. 3. - C. 415432.

10 Atindéhou R. B., Gueyie* J. P., Amenounve E. K. Financial intermediation and economic growth: evidence from Western Africa //Applied Financial Economics. - 2005. - T. 15. - N 11. - C. 777-790.

11 Mehl A., Vespro C., Winkler A. 12. Financial sector development in South-Eastern Europe: quality matters //Financial development, integration and stability: evidence from central, eastern and southeastern Europe. - 2006. - C. 186.

12 Ang J. B., McKibbin W. J. Financial liberalization, financial sector development and growth: evidence from Malaysia//Journal of development economics. - 2007. - T. 84. - N 1. - C. 215-233.

13 Khan M. A., Qayyum A. Trade, financial and growth nexus in Pakistan. - Economic Analysis Working Papers, 2007. - 2007, 14.

14 Kenourgios D., Samitas A. Financial development and economic growth in a transition economy: Evidence for Poland //Journal of Financial Decision Making. - 2007. - T. 3. - N 1. - C. 35-48.

15 Hagmayr B., Haiss P. R., Sümegi K. Financial sector development and economic growth-evidence for southeastern Europe //Available at SSRN 968253. 2007.

16 Saci K., Holden K. Evidence on growth and financial development using principal components // Applied Financial Economics. - 2008. - T. 18. - N 19. - C. 1549-1560.

17 Ağayev S. Geçiş Ekonomilerinde Liberalleşmenin Ekonomik Büyüme Üzerinde Etkisi.// Çukurova Üniversitesi Sosyal Bilimler Enstitüsü Dergisi. - 2012. - T. 21. - N 3.

18 Altıntaş H., Ayrıçay Y. Türkiye'de finansal gelişme ve ekonomik büyüme ilişkisinin sınır testi yaklaşımılla analizi: 1987-2007. // Anadolu Üniversitesi Sosyal Bilimler Dergisi.- 2010. - N.10. - C. 71-98.

19 Adnan Hye Q. M., Islam F. Does financial development hamper economic growth: empirical evidence from Bangladesh //Journal of Business Economics and Management. - 2013. - T. 14. - N 3. C. 558-582.

20 Jedidia K. B., Boujelbène T., Helali K. Financial development and economic growth: New evidence from 
Tunisia //Journal of Policy Modeling. - 2014. - T. 36. N 5. - C. 883-898.

21 Batuo M., Mlambo K., Asongu S. Linkages between financial development, financial instability, financial liberalisation and economic growth in Africa // Research in International Business and Finance. - 2018. - T. 45. - C. 168-179.

22 Soultanaeva A. Financial intermediation and economic growth: Evidence from the Baltic countries // Umeå economic studies. - 2010. - N 817.

23 Cojocaru L. et al. Financial development and economic growth in transition economies: Empirical evidence from the CEE and CIS countries //University of Delaware, Working Paper. - 2011. - T. 22.

24 Aydın M. K., Ak M. Z., Altıntaş N. Finansal Gelişme'nin Büyüme'ye Etkisi: Türkiye Özelinde Nedensellik Analizi //Maliye Dergisi. - 2014. - T. 167. - C. 149-162.

25 Mercan M., Göçer İ. The effect of financial development on economic growth in BRIC-T countries: Panel data analysis //Journal of Economic and Social Studies. - 2013. - T. 3. - N 1. - C. 199.

26 Dudian M. et al. Financial development and economic growth in Central and Eastern Europe // Theoretical and Applied Economics. - 2013. - T. 20. N 8. - C. 59-68.

27 Akinci G. Y., Akinci M., Yilmaz Ö. Financial development-economic growth nexus: A panel data analysis upon OECD countries //Hitotsubashi Journal of Economics. - 2014. - C. 33-50.

28 Arıç K. H. The effects of financial development on economic growth in the European Union: a panel data analysis //International journal of economic practices and theories. -2014 . - T. 4. - N 4. - C. 466-471.

29 Petkovski M., Kjosevski J. Does banking sector development promote economic growth? An empirical analysis for selected countries in Central and South Eastern Europe //Economic research-Ekonomska istraživanja. - 2014. - T. 27. - N 1. - C. 55-66.

30 Obradović S., Grbić M. Causality relationship between financial intermediation by banks and economic growth: Evidence from Serbia //Prague Economic Papers. - 2015. - T. 24. - N 1. - C. 60-72.

31 Dumitrescu E. I., Hurlin C. Testing for Granger non-causality in heterogeneous panels //Economic modelling. - 2012. - T. 29. - N 4. - C. 1450-1460.

32 Pesaran M. H. A simple panel unit root test in the presence of cross-section dependence //Journal of applied econometrics. - 2007. - T. 22. - N 2. - C. 265312.

33 De Hoyos R. E., Vasilis S. Testing for crosssectional dependence in panel-data models. Stata Journal, 6 (4): 482-496//View at. - 2006. - T. 6. N 4. - C. 482-490.

34 Syzdykova A., Tanrıven C., Nahipbekova, S., Kuralbayev, A. The effects of changes in oil prices on the Russian Economy// Revista Espacios. - 2019. - T. 40. - N14. - C. 39-52.

35 Tatoğlu F. Y. Panel zaman serileri analizi // İstanbul: Beta Yayınları. - 2017.

\section{References}

1 Syzdykova A. Doğrudan yabancı yatırımlar ve ekonomik büyüme ilişkisi: geçiş ülkeleri için panel veri analizi //Journal of Research in Economics. - 2020. - T. 4. - N 1. - C. 78-90.

2 Williamson O. E. Transaction cost economics //Handbook of new institutional economics. - Springer, Berlin, Heidelberg, 2008. - C. 41-65.

3 Hassan M. K., Sanchez B., Yu J. S. Financial development and economic growth: New evidence from panel data //The Quarterly Review of economics and finance. - 2011. - T. 51. - N 1. - C. 88-104.

4 Liang Q., Jian-Zhou T. Financial development and economic growth: Evidence from China//China economic review. - 2006. - T. 17. - N. 4. - C. 395-411.

5 Ductor L., Grechyna D. Financial development, real sector, and economic growth //International Review of Economics \& Finance. - 2015. - T. 37. - C. 393-405.

6 Ayadi R. et al. Financial development, bank efficiency, and economic growth across the Mediterranean //Economic and social development of the Southern and Eastern Mediterranean countries. Springer, Cham, 2015. - C. 219-233.

7 Ak M. Z., Altıntaş N., Şimşek A.S. Türkiye'de finansal gelişme ve ekonomik büyüme ilişkisinin nedensellik analizi// Doğuş Üniversitesi Dergisi. - 2016. - T. 17. - N 2. - C. 151-160.

8 Afşar A. Finansal gelişme ile ekonomik büyüme arasındaki ilişki //Muhasebe ve Finansman Dergisi. - 2007. - N 36. - C. 188-198.

9 Ghirmay T. Financial development and economic growth in Sub-Saharan African countries: evidence from time series analysis //African Development Review. - 2004. - T. 16. - №. 3. - C. 415432.

10 Atindéhou R. B., Gueyie* J. P., Amenounve E. K. Financial intermediation and economic growth: evidence from Western Africa //Applied Financial Economics. - 2005. - T. 15. - N 11. - C. 777-790.

11 Mehl A., Vespro C., Winkler A. 12. Financial sector development in South-Eastern Europe: quality matters //Financial development, integration and stability: evidence from central, eastern and southeastern Europe. - 2006. - C. 186.

12 Ang J. B., McKibbin W. J. Financial liberalization, financial sector development and growth: evidence from Malaysia//Journal of development economics. - 2007. - T. 84. - N 1. - C. 215-233.

13 Khan M. A., Qayyum A. Trade, financial and growth nexus in Pakistan. - Economic Analysis Working Papers, 2007. - N 2007, 14.

14 Kenourgios D., Samitas A. Financial development and economic growth in a transition economy: Evidence for Poland //Journal of Financial Decision Making. - 2007. - T. 3. - N 1. - C. 35-48.

15 Hagmayr B., Haiss P. R., Sümegi K. Financial sector development and economic growth-evidence for southeastern Europe //Available at SSRN 968253. 2007.

16 Saci K., Holden K. Evidence on growth and financial development using principal components // Applied Financial Economics. - 2008. - T. 18. - N 19. - C. 1549-1560. 
17 Ağayev S. Geçiș Ekonomilerinde Liberalleşmenin Ekonomik Büyüme Üzerinde Etkisi.// Çukurova Üniversitesi Sosyal Bilimler Enstitüsü Dergisi. - 2012. - T. 21. - N 3.

18 Altıntaş H., Ayrıçay Y. Türkiye'de finansal gelişme ve ekonomik büyüme ilişkisinin sınır testi yaklaşımıyla analizi: 1987-2007. // Anadolu Üniversitesi Sosyal Bilimler Dergisi.- 2010. - N10. - C. 71-98.

19 Adnan Hye Q. M., Islam F. Does financial development hamper economic growth: empirical evidence from Bangladesh //Journal of Business Economics and Management. - 2013. - T. 14. - N 3. C. $558-582$.

20 Jedidia K. B., Boujelbène T., Helali K. Financial development and economic growth: New evidence from Tunisia //Journal of Policy Modeling. - 2014. - T. 36. N 5. - C. 883-898.

21 Batuo M., Mlambo K., Asongu S. Linkages between financial development, financial instability, financial liberalisation and economic growth in Africa // Research in International Business and Finance. - 2018. - T. 45. - C. 168-179.

22 Soultanaeva A. Financial intermediation and economic growth: Evidence from the Baltic countries // Umeå economic studies. - 2010. - N 817.

23 Cojocaru L. et al. Financial development and economic growth in transition economies: Empirical evidence from the CEE and CIS countries //University of Delaware, Working Paper. - 2011. - T. 22.

24 Aydın M. K., Ak M. Z., Altıntaş N. Finansal Gelişme'nin Büyüme'ye Etkisi: Türkiye Özelinde Nedensellik Analizi //Maliye Dergisi. - 2014. - T. 167. - C. 149-162.

25 Mercan M., Göçer İ. The effect of financial development on economic growth in BRIC-T countries: Panel data analysis //Journal of Economic and Social Studies. - 2013. - T. 3. - N 1. - C. 199.
26 Dudian M. et al. Financial development and economic growth in Central and Eastern Europe // Theoretical and Applied Economics. - 2013. - T. 20. N 8. - C. 59-68.

27 Akinci G. Y., Akinci M., Yilmaz Ö. Financial development-economic growth nexus: A panel data analysis upon OECD countries //Hitotsubashi Journal of Economics. - 2014. - C. 33-50.

28 Arıç K. H. The effects of financial development on economic growth in the European Union: a panel data analysis //International journal of economic practices and theories. -2014 . - T. 4. - N. 4. - C. 466-471.

29 Petkovski M., Kjosevski J. Does banking sector development promote economic growth? An empirical analysis for selected countries in Central and South Eastern Europe //Economic research-Ekonomska istraživanja. - 2014. - T. 27. - N 1. - C. 55-66.

30 Obradović S., Grbić M. Causality relationship between financial intermediation by banks and economic growth: Evidence from Serbia //Prague Economic Papers. - 2015. - T. 24. - N 1. - C. 60-72.

31 Dumitrescu E. I., Hurlin C. Testing for Granger non-causality in heterogeneous panels //Economic modelling. - 2012. - T. 29. - N. 4. - C. 1450-1460.

32 Pesaran M. H. A simple panel unit root test in the presence of cross-section dependence //Journal of applied econometrics. - 2007. - T. 22. - N. 2. - C. 265312.

33 De Hoyos R. E., Vasilis S. Testing for crosssectional dependence in panel-data models. Stata Journal, 6 (4): 482-496//View at. - 2006. - T. 6. N 4. - C. 482-490.

34 Syzdykova A., Tanrıven C., Nahipbekova, S., Kuralbayev, A. The effects of changes in oil prices on the Russian Economy// Revista Espacios. - 2019. - T. 40. - N14. - C. 39-52.

35 Tatoğlu F. Y. Panel zaman serileri analizi. İstanbul: Beta Yayınları, 2017.

\section{Авторлар туралы мәліметтер}

Сыздықова А.О. - хат-хабаршы авторы, қаржы және бухгалтерлік есеп кафедрасының $\mathrm{PhD}$ доктор, доцент міндетін атқарушы, Қожа Ахмет Ясауи атындағы Халықаралық қазақ-түрік университеті, Түркістан, Қазақстан. orcid.org/0000-0002-1377-0026

Нахипбекова C. - PhD докторы, Мемлекеттік басқару және аймақтық даму кафедрасы, Қожа Ахмет Ясауи атындағы Халықаралық қазақ-түрік университеті, Түркістан, Қазақстан. orcid.org/0000-0002-7461-0384

Масадиков X. - PhD докторы, Мемлекеттік басқару және аймақтық даму кафедрасы, Қожа Ахмет Ясауи атындағы Халықаралық қазақ-түрік университеті, Түркістан, Қазақстан. orcid.org/0000-0002-0877-8859

Тилеуова С. - магистр оқытушы Қаржы және бухгалтерлік есеп кафедрасы, Қожа Ахмет Ясауи атындағы Халықаралық қазақ-түрік университеті, Түркістан, Қазақстан. orcid.org/0000-0002-5374-018X

\section{Information about the authors}

A.O. Syzdykova - corresponding author, PhD of Finance and Accounting Department, Khoja Akhmet Yassawi International Kazakh-Turkish University, Turkestan, Kazakhstan. orcid.org/0000-0002-1377-0026

S. Nakhipbekova - PhD of Department of Public administration and regional development, Khoja Akhmet Yassawi International Kazakh-Turkish University, Turkestan, Kazakhstan. orcid.org/0000-0002-7461-0384 
K. Massadikov - PhD of Department of Public administration and regional development, Khoja Akhmet Yassawi International Kazakh-Turkish University, Turkestan, Kazakhstan. orcid.org/0000-0002-0877-8859

S. Tileuova - Lecturer of Finance and Accounting Department, Khoja Akhmet Yassawi International KazakhTurkish University, Turkestan, Kazakhstan. orcid.org/0000-0002-5374-018X

Дата поступления рукописи: 19.01.2021

Прошла рецензирование: 18.02.2021

Принято решение о публикации: 28.02.2021

Received: 19.01.2021

Reviewed: 18.02 .2021

Accepted: 28.02.2021

Қарастыруға қабылданды: 19.01.2021

Рецензиялауды өтті: 18.02.2021

Жариялауга қабылданды: 28.02.021 